\title{
Survey of possible pathogenic organisms found in urine and vaginal swab samples of selected female population in Lagos, Nigeria
}

\author{
T.S. OLUSEGUN-JOSEPH * and V.M. KILLANEY
}

Department of Biological Science, Yaba College of Technology, Yaba Lagos. Nigeria.

"Corresponding author; E-mail: shadefame@gmail.com, Tel: +2348056716288

\begin{abstract}
Urinary Tract Infection (UTI) is caused by the presence and growth of microorganisms and females are more at risk of the infection. This survey was carried out to determine the prevalence of pathogenic organisms other than bacteria in urine and vaginal swabs of some selected female individuals and to determine the suitable sample material appropriate for identification of such organisms. Samples were collected from 200 female students of Yabatech and 200 patients attending General Hospital Lagos Island. The female students' and patients' age ranged from 16-55 years. Questionnaires were also administered. A total of 400 samples were collected and examined microscopically and also cultured for organisms' growth. The organisms encountered were Yeast cells, Pus cells and Trichomonas vaginalis. 5(2.5\%) positive samples with Trichomonas vaginalis were detected among the examined patients while none of the students were found infected with Trichomonas vaginalis. Yeast cells were the most frequently encountered organism while Trichomonas were the least encountered. The vaginal swab samples yielded more organisms than urine samples. Age group 31-35 years were observed to have the highest percentage growth rate of cultured organisms with students having $87.5 \%$ while the patients had $48.8 \%$. Vaginal discharge was the commonest symptom identified among the examined individuals with $68(34.0 \%)$ responses. No statistical significance was observed among results obtained for both students and patients. Sex education should be introduced as a means of increasing students' awareness of infections and proper sanitation enforced by the institution.
\end{abstract}

(C) 2016 International Formulae Group. All rights reserved.

Keywords: UTI, Trichomonas, Yeast cells, Pyuria, Vaginitis, Hygiene.

\section{INTRODUCTION}

Urine, a liquid by-product of the body is usually inspected and examined by many physicians for medical purposes, the color and other attributes of urine serves as indicator of certain diseases. The presence of certain organisms in the urine is linked to urinary infection in humans. Yeastlike organisms when discovered in the urine signify infection of either the upper or lower urinary tracts, colonization of the bladder, or contamination of the urine sample. Many yeast infections are superficial in nature, but some may represent life-threatening, invasive disease (Kauffman et al., 2011). The presence of Pus cells in urine (pyuria) is a definite indication of some infection in the lower or upper urinary tract. The organisms responsible for genital infections are generally fastidious and often difficult to culture (Ronald and Alfa, 1996). 
Urinary Tract Infection (UTI) is described as the microbial invasion of any tissues of the urinary tract. The number of urine samples in comparison with the other specimens in medical microbiology laboratories is very large (Behzadi et al., 2010). Women are more prone to urinary tract infections. Organisms such as $T$. vaginalis infects the urethra as well as the vagina, as such, urine represents potential source for microscopic examination (Wallin et al., 1981). Sexually transmitted diseases (STI) and reproductive tract infections often present with vaginal discharge (Leon et al., 2009). The incidence of abnormal vaginal discharge in female of reproductive age is found to be the commonest problem in clinical medicine and gynecological.

Sexually transmitted infections (STI) are worldwide public health problem, with most infections affecting the reproductive system causing reproductive tract infections. The implicated organisms in the transmission of sexually transmitted infections belong to the group bacteria, viruses, yeast and protozoa (Oyewole et al., 2010). More than 95\% of UTI cases are caused by Bacteria, which are the major causative organisms for UTI (Amaeze et al., 2013). The infection is common among sexually active males and females especially during the child bearing age (Egbere et al., 2009). These infections continue to present major health, social, and economic problems in the developing world. The prevalence rates apparently are far higher in developing countries where STI diagnostic tests are not easily available. Most of the sexually transmitted infection are prevalent in Nigeria and constitute one of the major public health problems (Okonko et al., 2012).

The most frequently seen STI include chlamydia, gonorrhea, and syphilis which are bacterial infection, Viral STIs include genital herpes, AIDS, while Parasitic STIs include trichomoniasis. Trichomoniasis is a sexually transmitted infection caused by the protozoan parasite Trichomonas vaginalis, often referred to as the "neglected" sexually transmitted infection. It is the most common non-viral sexually transmitted disease worldwide (Opara et al., 2009) and frequently encountered among $50 \%$ of women complaining of abnormal pain, vaginal discharge and itching. The infection often leads to vaginitis, cervicitis in women and urethritis in men and acute inflammatory disease of the genital mucosa, urinary tract, fallopian tubes and pelvic (Egbere et al., 2009). It may be asymptomatic, symptoms of infection includes frothy, yellowish green vaginal discharge with a strong odour, lower abdominal pain, low birth weight infants, preterm labor, predisposition to cervical cancer, atypical pelvic inflammatory disease, infertility, itching and burning sensation in women, urethral discharge in men, complication in the fetus and newborn (Valadkhani et al., 2010). Trichomoniasis is associated with important public health problems which including amplification of Human Immunodeficiency virus (HIV) transmission.

The estimated annual incidence of Trichomoniasis worldwide exceeds that of chlamydia and gonorrhea combined, yet, there are no established screening, surveillance, or control programs for infected individuals (Van der Pol, 2007). The World Health Organization (2000) estimated that 180 million cases of Trichomonal infection are acquired annually worldwide (Johnston and Mabey, 2008). In tropical Africa, a prevalence rate among the female patients range between 5-37\% (Bakare et al., 2002). In Nigeria, there are several documented reports on the prevalence of Trichomonas vaginalis. The prevalence of this infection depends on factors such as age, sexual activity, and number of sex partners (Leon et al., 2009).

Various studies have been establish to undertaken the etiologic agent of abnormal vaginal discharge in the environment. Nwankwo et al. (2010) collected High vaginal specimens from 587 patients and the major pathogen found were Candida albicans 177(70.0\%), Trichomonas vaginalis 14(5.5\%) and Gardnerella vaginalis 62(24.5\%). The 
unmarried ladies were found to have the higher positive result and it was concluded that multiple sexual partners increase the rate of infection (Nwankwo et al., 2010). In Nigeria, where human immunodeficiency virus (HIV) seroprevalence still appears to be on the rise, increase attention to sexually transmitted diseases (STDs), awareness and treatment would likely help slow the epidemic. Cases identification, which is one of the two important components of sexually transmitted diseases (STD) control program, is extremely difficult in most parts of the world as these diseases are considered as social problem and frequently surrounded by prejudices and poor information. The most obvious approach to STI diagnosis is direct detection of microorganisms through the use of microscopy and appropriate staining or wet preparation to visualize pathogens. Other more sensitive methods such as Culture, antigen detection, or nucleic acid detection may have more complex technical requirements for optimal test performance and may increase the interval between testing and the availability of test results. Microscopy, particularly when performed while patients are present, may provide immediate results to guide management decisions. This work was designed to survey the prevalence of other possible pathogenic organisms apart from bacteria in urine and vaginal swabs of sampled individuals, to determine the suitable sample material appropriate for identification of such organisms and to assess the knowledge and perception of the selected individuals.

\section{MATERIALS AND METHODS} Study areas and population

Two centers were used to obtain samples, the Health Center of Yaba College of Technology, which is an institution owned by the Federal Government of Nigeria and the Parasitology Laboratory of General Hospital Lagos, which is owned by the Lagos State Government of Nigeria.

\section{Administration of Questionnaire}

Questionnaires were administered to students of Yabatech at the Medical Center to collect their socio-demographic information including age, area of residence, behavioral variables, marital status, type of water used in showering and information about sexually transmitted diseases. The data and information of the patients attending the General Hospital were also collected.

\section{Specimen collection, transport, and preparation}

Urine and Vaginal swab samples were collected from students and patients who gave their consent. Each subject was given a sterile plastic bottle to collect mid-stream urine after they were taught how to collect it aseptically; the collected samples were transported to the laboratory. Bar-coded numbers were used to ensure obscurity of students and patients, to facilitate laboratory procedure and minimize the chances of error during the handling of samples. Cotton swabs for wet mount examination were placed into test tube containing saline while the ones for culture were placed into broth medium.

\section{Sample analysis}

Wet mount preparations of the vaginal swabs and urine samples were examined under the microscope for the presence of organisms. In most cases, urine and vaginal swabs was examined within 30 minutes to 50 minutes of collection. Urine specimens were centrifuged, the supernatant were decanted and the sediment were examined under the microscopically at high magnification for pus cells, yeast-like cells, red blood cells, epithelial cells, crystals and Trichomonas vaginalis. Pus cells $>5$ per high power field were also considered significant for infection (Houston, 1969).

The culture for organisms was carried out using Broth culture technique. Urine and vaginal samples were inoculated into separate Bijou bottles containing broth and incubated for 5 days at $37^{\circ} \mathrm{C}$. Cultures were evaluated 
daily, by microscopic examination for up to 5 days. Incubator temperature was checked and recorded daily. All observations and results were documented.

\section{Statistical analysis}

Calculation to determine prevalence was done by dividing the proportion of persons with samples positive for organisms by the total number of individuals sampled. Descriptive statistics (Mean, Chi-Square) with SPSS package 2007 was used to analyze the data obtained, for all statistical tests in this study, $\mathrm{P}<0.05$ was considered significant.

\section{RESULTS}

A total of 200 female students had their urine and vaginal swabs examined. None of them had Trichomonas vaginalis infection $(0.0 \%), 86(43.0 \%)$ had yeast cells and $23(11.5 \%)$ had pus cells when their vaginal swabs were examined (Table 1). However, when the urine samples were examined, $41(20.5 \%)$ had Yeast cells, 30(15.0\%) had pus cells and none had Trichomonas vaginalis as shown in Table 2.

About 200 female patients from the General Hospital had their urine and vaginal swabs equally examined. $5(2.5 \%)$ had Trichomonas vaginalis infection, 33(16.5\%) had yeast cells and 19(9.5\%) had pus cells from the examination of their vaginal swabs (Table 1). The examination of the urine samples revealed 5 patients $(2.5 \%)$ infected with Trichomonas vaginalis, $30(15.0 \%)$ with yeast cells and 19(9.5\%) with pus cells as shown in Table 2.

The urine samples and vaginal swabs collected from both students and patients were cultured to observe the growth. Students in the age group 26 - 30 had the highest observed growth from the culture sample while patients in the age group 36 - 40 had the highest observed growth (Table 3 ).

The questionnaire administered to students was used to assess symptoms observed by the sampled individuals. Vaginal discharge was the commonest symptom observed which was followed by itching and abdominal pain as shown in Table 4. Students belonging to age group 21-25 had the highest number of complaint for both vaginal discharge 25(28.4\%) and itching 20(22.7\%).

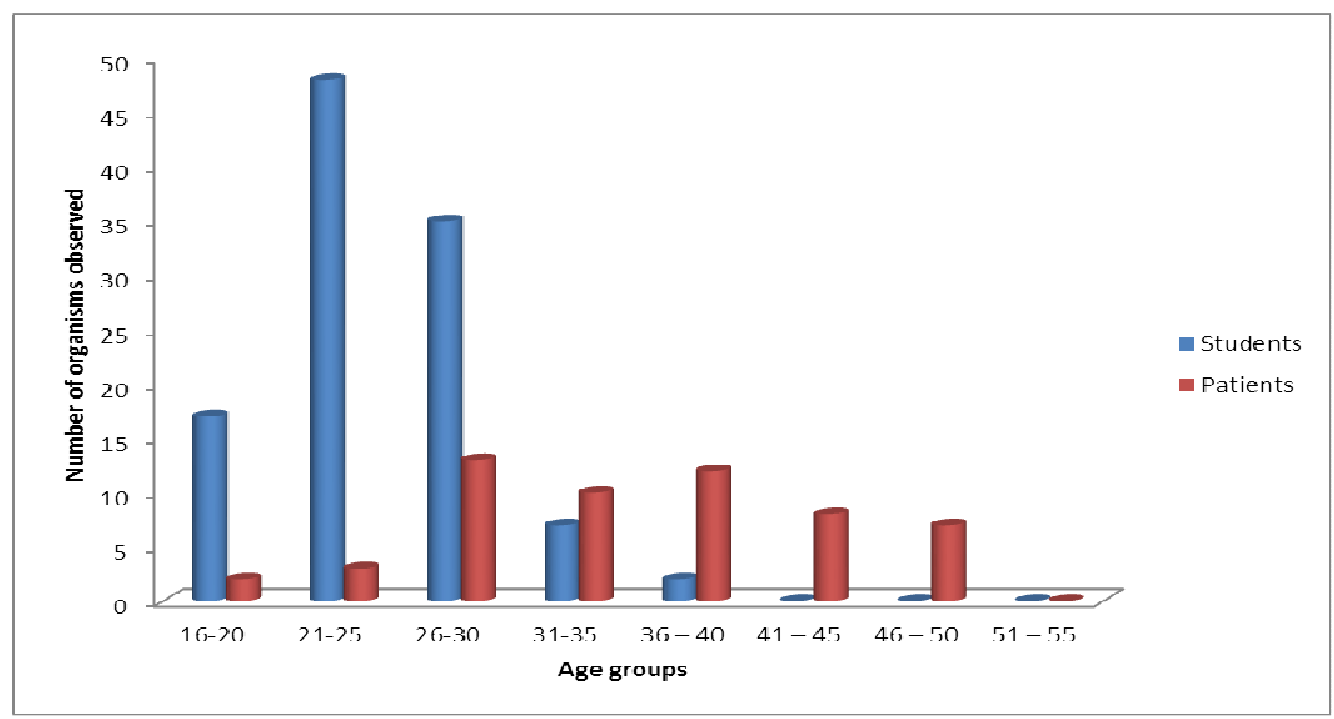

Figure 1: Total number of Organisms observed from vaginal swabs of both Students and Patients. 


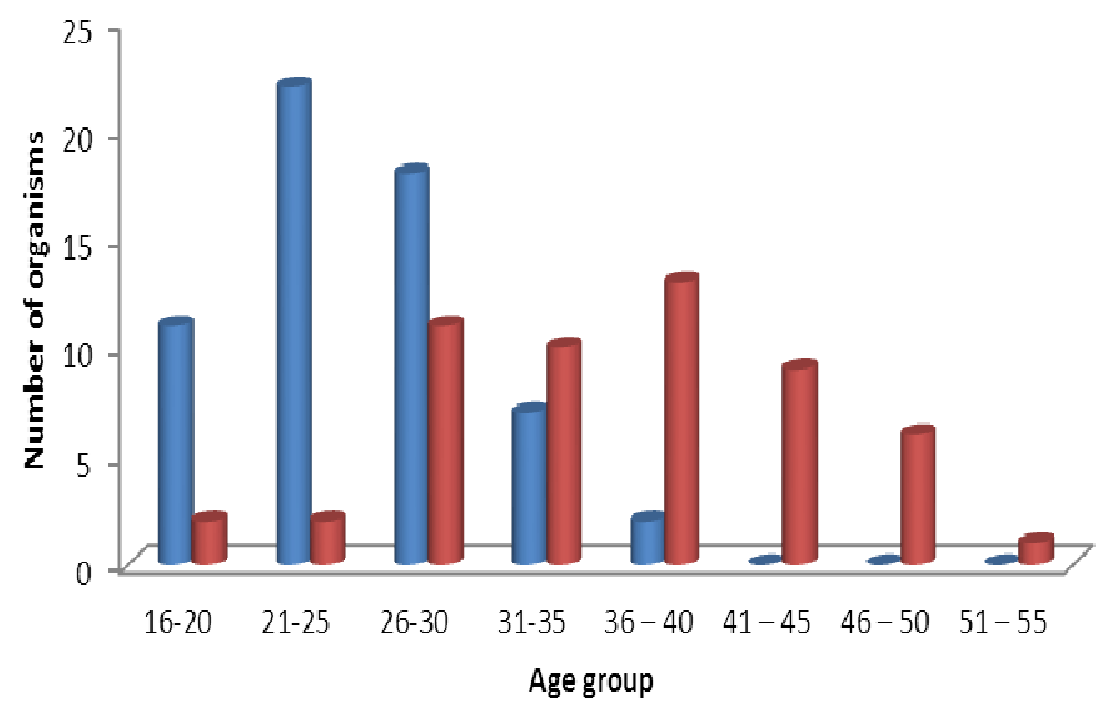

nstudents patients

Figure 2: Organisms Observed from Urine of sampled students and patients.

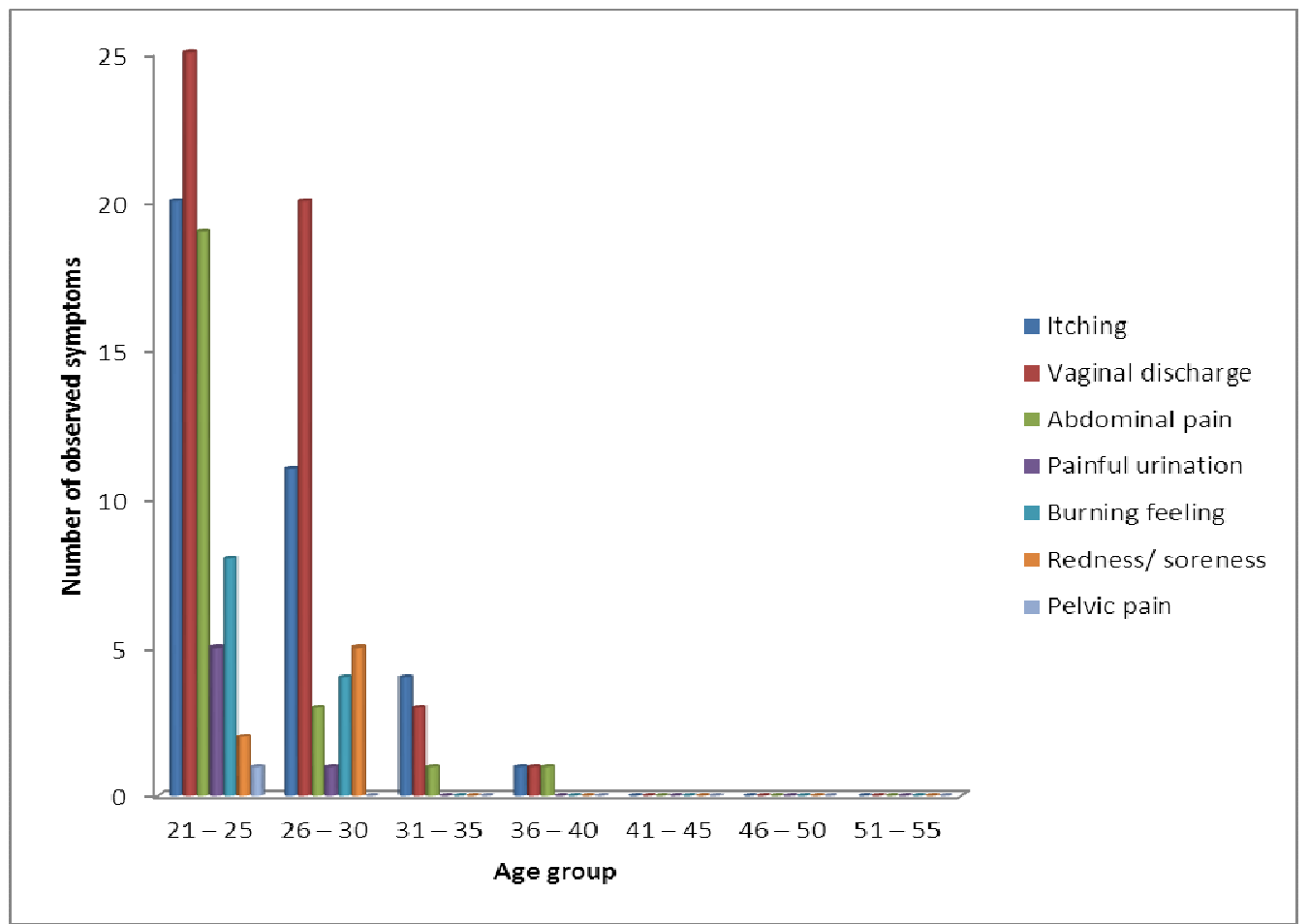

Figure 3: Multiple Bar chart of observed symptoms in samples individual with identified organisms. 
T.S. OLUSEGUN-JOSEPH et al. / Int. J. Biol. Chem. Sci. 10(4): 1840-1852, 2016

Table 1: Organisms Observed from vaginal swabs of sampled students and patients.

\begin{tabular}{|c|c|c|c|c|c|c|c|c|c|c|c|c|}
\hline \multirow[t]{2}{*}{ Age Group } & \multicolumn{2}{|c|}{ No Examined } & \multicolumn{2}{|c|}{ Trichomonas. vaginalis } & \multicolumn{2}{|l|}{ Yeast } & \multicolumn{2}{|l|}{ Pus Cells } & \multicolumn{2}{|c|}{$\begin{array}{c}\text { Total No with } \\
\text { Organisms observed }\end{array}$} & \multicolumn{2}{|c|}{$\%$ of Organisms observed } \\
\hline & Students & Patients & Students\% & Patients\% & $\begin{array}{l}\text { Students } \\
1 \%\end{array}$ & $\begin{array}{l}\text { Patients/ } \\
\%\end{array}$ & $\begin{array}{l}\text { Students/ } \\
\%\end{array}$ & $\begin{array}{l}\text { Patients/ } \\
\%\end{array}$ & Students & Patient & Students & Patients \\
\hline $16-20$ & 44 & 10 & $0(0.0)$ & $0(0.0)$ & $\begin{array}{l}13 \\
(29.5)\end{array}$ & $2(20.0)$ & $4(9.1)$ & $0(0.0)$ & 17 & 2 & 38.6 & 20.0 \\
\hline $21-25$ & 88 & 10 & $0(0.0)$ & $0(0.0)$ & $\begin{array}{l}40 \\
(45.4)\end{array}$ & $1(10.0)$ & $8(9.1)$ & $2(20.0)$ & 48 & 3 & 54.5 & 30.0 \\
\hline $26-30$ & 57 & 36 & $0(0.0)$ & $1(2.8)$ & $\begin{array}{l}29 \\
(50.8)\end{array}$ & $8(22.2)$ & $6(10.5)$ & $4(11.1)$ & 35 & 13 & 61.4 & 36.1 \\
\hline $31-35$ & 8 & 34 & $0(0.0)$ & $2(5.9)$ & $3(37.5)$ & $5(14.7)$ & $4(50.0)$ & $3(8.8)$ & 7 & 10 & 87.5 & 29.4 \\
\hline $36-40$ & 3 & 41 & $0(0.0)$ & $1(2.4)$ & $1(33.3)$ & $6(14.6)$ & $1(33.3)$ & $5(12.2)$ & 2 & 12 & 66.6 & 29.3 \\
\hline $41-45$ & 0 & 33 & $0(0.0)$ & $0(0.0)$ & $0(0.0)$ & $5(15.1)$ & $0(0.0)$ & $3(9.1)$ & 0 & 8 & 0.0 & 24.2 \\
\hline $46-50$ & 0 & 32 & $0(0.0)$ & $1(3.1)$ & $0(0.0)$ & $5(15.6)$ & $0(0.0)$ & $2(6.3)$ & 0 & 7 & 0.0 & 21.9 \\
\hline $51-55$ & 0 & 4 & $0(0.0)$ & $0(0.0)$ & $0(0.0)$ & $1(25.0)$ & $0(0.0)$ & $0(0.0)$ & 0 & 1 & 0.0 & 25.0 \\
\hline Total & 200 & 200 & $0(0.0)$ & $5(2.5)$ & $86(43)$ & $33(16.5)$ & $23(11.5)$ & $19(9.5)$ & $109(54.5)$ & $56(28)$ & & \\
\hline
\end{tabular}


Table 2: Organisms Observed from Urine of sampled students and patients.

\begin{tabular}{|c|c|c|c|c|c|c|c|c|c|c|c|c|}
\hline \multirow[t]{2}{*}{ Age Group } & \multicolumn{2}{|c|}{ No Examined } & \multicolumn{2}{|c|}{$\begin{array}{l}\text { Trichomonas. } \\
\text { vaginalis }\end{array}$} & \multicolumn{2}{|l|}{ Yeast } & \multicolumn{2}{|l|}{ Pus Cells } & \multicolumn{2}{|c|}{$\begin{array}{l}\text { Total of Organisms } \\
\text { Observed }\end{array}$} & $\begin{array}{l}\text { \% } \\
\text { Observed }\end{array}$ & Organisms \\
\hline & Students & Patients & $\begin{array}{l}\text { Students/ } \\
\%\end{array}$ & $\begin{array}{l}\text { Patients } \\
\%\end{array}$ & $\begin{array}{l}\text { Students/ } \\
\%\end{array}$ & $\begin{array}{l}\text { Patients/ } \\
\%\end{array}$ & $\begin{array}{l}\text { Students/ } \\
\%\end{array}$ & $\begin{array}{l}\text { Patients/ } \\
\%\end{array}$ & students & Patient & Students & Patients \\
\hline $16-20$ & 44 & 10 & $0(0.0)$ & $0(0.0)$ & $8(18.2)$ & $2(20.0)$ & $3(6.8)$ & $0(0.0)$ & 11 & 2 & 25.0 & 20.0 \\
\hline $21-25$ & 88 & 10 & $0(0.0)$ & $0(0.0)$ & $15(17.0)$ & $1(10.0)$ & $7(8.0)$ & $1(10.0)$ & 22 & 2 & 25.0 & 20.0 \\
\hline $26-30$ & 57 & 36 & $0(0.0)$ & $1(2.8)$ & $13(22.8)$ & $7(19.4)$ & $5(8.8)$ & $3(8.3)$ & 18 & 11 & 31.6. & 30.6 \\
\hline $31-35$ & 8 & 34 & $0(0.0)$ & $2(5.9)$ & $4(50.0)$ & $4(11.8)$ & $3(50.0)$ & $4(11.8)$ & 7 & 10 & 87.5 & 29.4 \\
\hline $36-40$ & 3 & 41 & $0(0.0)$ & $1(2.4)$ & $1(33.3)$ & $5(12.2)$ & $1(33.3)$ & $7(17.1)$ & 2 & 13 & 66.7 & 31.7 \\
\hline $41-45$ & 0 & 33 & $0(0.0)$ & $0(0.0)$ & $0(0.0)$ & $5(15.2)$ & $0(0.0)$ & $4(12.1)$ & 0 & 9 & 0.0 & 27.3 \\
\hline $46-50$ & 0 & 32 & $0(0.0)$ & $1(3.1)$ & $0(0.0)$ & $5(15.6)$ & $0(0.0)$ & $0(0.0)$ & 0 & 6 & 0.0 & 18.3 \\
\hline $51-55$ & 0 & 4 & $0(0.0)$ & $0(0.0)$ & $0(0.0)$ & $1(25.0)$ & $0(0.0)$ & $0(0.0)$ & 0 & 1 & 0.0 & 25.0 \\
\hline Total & 200 & 200 & $0(0.0)$ & $5(2.5)$ & $41(20.5)$ & $30(15)$ & $19(9.5)$ & $19(9.5)$ & $60(30.0)$ & $54(27.0)$ & & \\
\hline
\end{tabular}


Table 3: The results of growth of Cultured Samples observed from students and patients.

\begin{tabular}{lllllll}
\hline \multirow{2}{*}{$\begin{array}{l}\text { Age } \\
\text { Group }\end{array}$} & \multicolumn{2}{l}{ Total No of cultured samples } & $\begin{array}{l}\text { No with } \\
\text { Growth }\end{array}$ & observed & \% with Observed Growth \\
\cline { 2 - 7 } & Students & Patients & Students & Patients & Students & Patients \\
\hline $16-20$ & 44 & 10 & 20 & 2 & 45.5 & 20.0 \\
$21-25$ & 88 & 10 & 60 & 3 & 68. & 30.0 \\
$26-30$ & 57 & 36 & 45 & 14 & 79 & 38.9 \\
$31-35$ & 8 & 34 & 7 & 20 & 87.5 & 58.8 \\
$36-40$ & 3 & 41 & 2 & 21 & 67 & 51.2 \\
$41-45$ & 0 & 33 & 0 & 10 & 0.0 & 30.3 \\
$46-50$ & 0 & 32 & 0 & 9 & 0.0 & 28.1 \\
$51-55$ & 0 & 4 & 0 & 1 & 0.0 & 25.0 \\
\hline
\end{tabular}

Table 4: Assessment of Observed Symptoms in sampled individual with identified Organisms.

\begin{tabular}{lllllllll}
\hline $\begin{array}{l}\text { Age } \\
\text { Group }\end{array}$ & $\begin{array}{l}\text { No } \\
\text { examined }\end{array}$ & Itching & $\begin{array}{l}\text { Vaginal } \\
\text { discharge }\end{array}$ & $\begin{array}{l}\text { Abdominal } \\
\text { Pain }\end{array}$ & $\begin{array}{l}\text { Painful } \\
\text { urination }\end{array}$ & $\begin{array}{l}\text { Burning } \\
\text { feeling }\end{array}$ & $\begin{array}{l}\text { Redness/ } \\
\text { soreness }\end{array}$ & $\begin{array}{l}\text { Pelvic } \\
\text { pain }\end{array}$ \\
\hline $16-20$ & 44 & $6(13.6)$ & $7(15.9)$ & $10(22.7)$ & $4(9.1)$ & $6(13.6)$ & $2(4.5)$ & $0(0.0)$ \\
$21-25$ & 88 & $20(22.7)$ & $25(28.4)$ & $19(21.6)$ & $5(5.7)$ & $8(9.1)$ & $2(2.3)$ & $1(1.1)$ \\
$26-30$ & 57 & $11(19.3)$ & $20(35.1)$ & $3(5.3)$ & $1(1.8)$ & $4(7.0)$ & $5(8.8)$ & $0(0.0)$ \\
$31-35$ & 8 & $4(50.0)$ & $3(37.5)$ & $1(12.5)$ & $0(0.0)$ & $0(0.0)$ & $0(0.0)$ & $0(0.0)$ \\
$36-40$ & 3 & $1(33.3)$ & $1(33.3)$ & $1(33.3)$ & $0(0.0)$ & $0(0.0)$ & $0(0.0)$ & $0(0.0)$ \\
$41-45$ & 0 & $0(0.0)$ & $0(0.0)$ & $0(0.0)$ & $0(0.0)$ & $0(0.0)$ & $0(0.0)$ & $0(0.0)$ \\
$46-50$ & 0 & $0(0.0)$ & $0(0.0)$ & $0(0.0)$ & $0(0.0)$ & $0(0.0)$ & $0(0.0)$ & $0(0.0)$ \\
$51-55$ & 0 & $0(0.0)$ & $0(0.0)$ & $0(0.0)$ & $0(0.0)$ & $0(0.0)$ & $0(0.0)$ & $0(0.0)$ \\
TOTAL & 200 & $42(21.0)$ & $56(28.0)$ & $34(17.0)$ & $10(5.0)$ & $18(9.0)$ & $9(4.5)$ & $1(0.5)$ \\
\hline
\end{tabular}

\section{DISCUSSION}

Urinary tract infections are common, and are most often caused by uropathogenic bacteria. UTI was usually diagnosed if the bacteria or pus cell count, or both were significant in an individual (Oladeinde et al., 2011). Less emphasis has being placed on other uropathogenic organisms. In view of this, the present survey focused on other causative agents of UTI other than bacteria. The potential pathogenic organisms encountered in this survey when the urine and vaginal swabs of sampled individuals were examined are Trichomonas vaginalis, yeast cells (Candida spp.) and pus cells. A total of 200 female students and 200 female patients had their urine and vaginal swabs examined.

When the wet mounts were examined microscopically, from 200 urine samples collected from the female students, $60(30 \%)$ had various pathogenic organisms while $54(27 \%)$ out of the 200 urine samples collected from the female patients indicated the presence of pathogenic organisms. Examination of the wet mounts of the Vaginal swab samples from 200 female student revealed that $109(54.5 \%)$ had the above mentioned organisms while $56(28 \%)$ out of the 200 female patients sampled had these organisms.

The vaginal swabs examination showed $86(43.0 \%)$ of the students, $38(16.5 \%)$ patients had yeast cells and $23(11.5 \%)$ of students and $19(9.5 \%)$ of patients had pus cells in their vaginal swabs. However, when the urine was observed 41(20.5\%) of the students, 30(15.0) patients had yeast infection and 19(9.5\%) of the students and $19(9.5 \%)$ of patients had pus cells in their urine. Similar pattern of infection was reported by Battikhi and Battikhi (2015) 
where they discovered that 53 of their positive samples revealed $32(26.0 \%)$ samples with pus cells, $12(9.7 \%)$ samples with red blood cells , 2 samples $(1.6 \%)$ with yeast cells and $1(0.8)$ with Trichomonas vaginalis infection. Onuoha and Fatokun (2014) in their study found a high percentage of pus cells $(35.5 \%)$ and yeast $(20 \%)$ cells out of the 200 urine samples they analyzed and they concluded that the high percentage of pus cells in the urine samples is an indication of the presence of urinary tract infection.

It was observed that the vaginal swab samples used in this study yielded more positive results than the urine samples for both students and patients, this findings agree with that of Amali et al. (2008) where the Candida $s p$. they found in HVS samples was higher $(19.31 \%)$ than was found in the urine sample $(8.45 \%)$ of same sampled individuals, but oppose the findings of Blake et al. (1999) where they found that 9 patients among their study population with negative vaginal wet mounts had positive urine specimens and therefore, they concluded that addition of a spun urine microscopic examination would significantly enhance detection of $T$.vaginalis without substantially increasing the cost of detection.

There were very few cases of trichomoniasis in this study, $2.5 \%$ (5 positive patients), and they were found distributed among the different age groups of the sampled female patients attending the hospital used. None of the students examined was found infected with Trichomonas vaginalis. There was no significant difference in the prevalence of trichomoniasis among the students and patients examined. This result is lower than the result obtained by Amali et al. (2008), they found out that Trichomonas vaginalis occurred in only $12(5.63 \%)$ HVS samples, and was the least cause of infection. They however found the infection in female students which is contrary to what was obtained in this study.

In a study carried out by Adeoye and Akande (2007) to determine the prevalence of
Trichomoniasis in outpatient women from two different hospitals in Lagos, they found a prevalence rate of $1.9 \%$ and $5.4 \%$ from each of the hospitals. They further reported a prevalence of $1.8 \%$ in the age group 21-30 years and they observed that none of the patients below 21 years had Trichomonasis.

Egbere et al. (2009) in their findings reported a prevalence of $1.81 \%$ Trichomonas vaginalis infection in patients aged between 20-40 years who also had vaginal discharge. In this recent survey, prevalence of $2.5 \%$ infected with Trichomonas vaginalis was obtained from patients in General Hospital, which falls in line with what these researchers obtained. The absence of Trichomonas vaginalis infection from the students examined in this study may possibly be as a result of the time spent between urinating, submission of sample and examination in the laboratory that was experienced during the survey.

Van der pol et al. (2007) also reported $3.1 \%$ of Trichomonas vaginalis infection among women of reproductive age in the United States. These they explained, may be due to keeping of multiple sex partner, consequently resulting to high rate of infection.

In line with what Adeoye and Akande, (2007) observed, this recent survey also recorded that the age group 21-25 had the highest prevalence $(45.4 \%)$ obtained for yeast cells and pus cells $(9.1 \%)$ in vaginal swabs of students. The high number recorded is a clear indication of UTI. This may be attributed to the fact that females within this age group are sexually active young adult. It is however clear from this finding that the prevalence of infection was much higher in females of younger age compared to older ones.

In recent times, the incidences of yeast infections have been reported to have greatly increased especially due to the widespread use of broad-spectrum antibiotics and immunosuppressive treatment (Olowe et al., 2014). The results obtained from the present study showed a high prevalence of yeast cells 
(Candida spp.) among students, and this may be due to the poor personal and sanitary behavior of the students, which are factors enhancing the transmission of the infection since the organism could be transmitted through common use of toilet seat.

Okonko et al. (2012) in their survey reported $27 \%$ prevalence of Candida albican and $1.5 \%$ Trichomonas vaginalis and they concluded that these organisms are the predominant STIs pathogen. Fusi Ngwa et al. (2012) also found a high rate of yeast vaginitis in women that they examined. Nwankwo et al. (2010) in their research, collected vaginal specimens from 587 patients attending Aminu Kano Teaching Hospital where the major pathogen found in the patients were Candida albicans $(70.5 \%)$ and Trichomonas vaginalis $(5.5 \%)$. The result they obtained is higher than the present study conducted among the students and patients. These differences in prevalence could be explained on the basis of differences on cultural, social and environmental factors. A study conducted by Moodley et al. (2002) had a lower prevalence of $6.0 \%$ infection with vulvovaginal candidiasis compared to the result observed in this study. Nimorsi et al. (2001) recorded the occurrence of Trichomonas in the genital urinary tract of 14(6.3\%) female inhabitant of Ikao village in Owan, Edo State, this also differs from the result obtained in this present study.

The pattern of infection according to age group obtained in this study revealed that both students and patients within the age group 31-35 had the highest observed growth of organisms in the samples cultured, followed closely by age group 26-30, and the lowest observed growth rate was found from age group 41-45 and above. The higher rate of isolation found in the age groups is probably related to the higher level of sexual activity in the females of the age group. Closely related to what was obtained in this study, Battikhi and Battikhi (2015) discovered in their study that age group 38-42 exhibited the highest prevalence of UTI while age group 28-32 showed higher percentage of isolates, they concluded that UTI increase with age. When Abdulazeez et al. (2006) assessed infection rates according to age in their study, they found the highest prevalence rate of $1.1 \%$ within 16-24 years of age bracket while the least $(0.2 \%)$ was recorded within the 45-54 years age-group. Their result is slightly in agreement with what was obtained in this present study.

A research conducted among women attending a health center in Iran by Mazloumi et al. (2008) to determine the prevalence of trichomoniasis showed a prevalence of $9.2 \%$ by culture and $3.1 \%$ by wet method. The result obtained in this present survey, differs from result of the study in Iran due to difference in location and to the unreliability of detection method.

According to Dahab et al. (2012), alteration in the balance of normal vaginal organisms can cause excessive growth of the bacteria that create vaginal discharge. In this present study the age group 21-25 had the highest recorded complain of vaginal discharge as symptom for UTI, followed by age group 26-30(35.1\%). Itching symptom was the next highest observed complain followed by abdominal pain among sampled individuals. In the research carried out by Dahab et al. (2012), vaginal discharge was the most common symptom in women with UTI $(15.1 \%)$, while other frequent symptoms were pruritus (12.3\%) and abdominal pain (12.5\%). Occasionally, many of the students may have been involve in unprotected sexual activities or unhygienic practices that could lead to these symptoms. There was no statistically significant difference between the organisms observed from the students and patients sampled.

\section{Conclusion}

The prevalence of Urinary infection in the community is a public health risk and other STIs constitute major burden that can enhance the susceptibility of an individual to acquire or transmit HIV through sexual 
contact. It will continue to be a non-reportable disease with no government funded control programs, quietly perpetuating the spread of HIV. As we wait for more experimental evidence, the clinicians should routinely screen all pregnant women for the infection and appropriate treatment be given early to prevent the spread of STIs and possible implication on the newborn baby. Emphasis must be placed on the youths; education programs should be implemented to combat the endemicity of urinary infection in the world. The policy makers need to enlighten the community on girl child education, safe sex and good hygiene, and to institute policies that will make health care service accessible, affordable and standard. Although, a relatively low rate of the infection was recorded in this study, this research finding could still be very useful in the management and control of the infection in the society and could also serve as baseline information for future studies. Proper sanitation and personal hygiene should be strictly observed among the females.

\section{COMPETING INTERESTS}

The authors declare that they have no competing interests.

\section{AUTHORS' CONTRIBUTIONS}

TSO-J designed the study and revised the final draft of the manuscript while both authors (TSO-J and VMK) carried out the laboratory work and drafting of the manuscript.

\section{ACKNOWLEDGMENTS}

We acknowledge the technical assistance provided by Yaba College of Technology Medical Centre laboratory staff and the Parasitology Laboratory staff of General Hospital, Lagos.

\section{REFERENCES}

Abdulazeez A, Alo E, Livingstone R. 2007. Epidemiology of Urino-genital Trichomoniasis in north-eastern state,
Nigeria. The Internet Journal of Parasitic Diseases, 2(2): 10-55.

Adeoye GO, Akande AH. 2007. Epidemiology of Trichomonas vaginalis among women in Lagos Metropolis, Nigeria. Pakistan Journal of Biology Science, 10(3): 2198-201. ISSN 10288880

Amaeze NJ, Abah AU, Okoliegbe IN. 2013. Prevalence and antibiotic susceptibility of uropathogens among patients attending University of Abuja Teaching Hospital, Gwagwalada, Abuja. International Journal of Medicine and Medical Sciences, 5(10): 460-466.

DOI: 10.5897/IJMMS2013.0958

Amali O, Indinyero M, Umeh E, Awodi N. 2009. Urinary tract Infection among Female Students of the University of Agriculture, Makurdi, Benue state, Nigeria. The Internet Journal of Microbiology, 7(1):10-53.

Asekun-Olarinmoye EO, Oladele EA. 2009. Condom Use Undergraduates in Osun State, Nigeria: Implication for Sexually Transmitted Infection (STIs)/HIV Prevention. Research Journal of Medical Sciences, 3(6): 179-187.

Avwioro OG. 2011. Diagnosis of Trichomoniasis in Pap smears. European Journal of Experimental Biology, 1(1): 10-13.

Bakare RA, Oni AA, Umar US, Fayemiwo SA, Fasina NA, Adewole IF, Shokunbi WA. 2002. Prevalence of Trichomonas vaginalis among Commercial sex workers in Ibadan, Nigeria. African Journal of Clinical and Experimental Microbiology, 3(2): 64-68.

Battikhi MN, Battikhi QG. 2015. Correlation of Urinary Tract Infection Pathogens, Antibiogram and Age Group in Pregnant Women. $J$ Microbiol Exp 2(4): $00054 . \quad$ DOI: 10.15406/jmen.2015.02.00054

Behzadi P, Behzadi E, Yazdanbod H, Aghapour R,Akbari Cheshmeh M, 
Salehian Omran D. 2010. Urinary Tract Infections Associated with Candida albicans. Maedica (Buchar), 5: 277279.

Centers for Disease Control and Prevention 2007.Guidelines for Treatment of Sexually Disease. Morb. Mortal wkly Rep., 51(6): 1-84.

Dahab MM, Koko WS, Osman EE, Hilali AHM. 2012. Prevalence and Transmission of Trichomonas vaginalis Infection among Women in Khartoum state, Sudan. Journal of Public Health and Epidemiology, 4(2): 34-38.

Egbere J, Dashen O, Zakari MM, Sango SP. 2009. Trichomonas vaginalis and human immunodeficiency virus (HIV) in woman. Nigerian Journal of Microbiology, 23(1): 1864-1868.

Fusi Ngwa CNK,Payne VK,Asakizi AN.2012. Non-classical reproductive tract infections on the rise in women in Dschang,Cameroon. Int. J. Biol. Chem. Sci., 6(5): 2016-2025. DOI : http://dx.doi.org/10.4314/ijbcs.v6i5.11

Houston IB.1969. Measurement of pyuria in urinary tract infections. Arch. Dis. Child., 44: 480-482.

Johnston VJ, Mabey DC. 2008. Global Epidemiology and Control of Trichomonas vaginalis. Current Opinion in Infectious Diseases, 21: 5664.

Kauffman CA, Fisher JF, Sobel JD, Newman CA.2011.Candida Urinary Tract Infections-Diagnosis. Clinical Infectious Diseases, 52(S6): S452S456.

Leon SR, Kelika AK, Bernstem KT, Pajuelo JB, Rosasco A, Caceres CF, Coates TJ, Klausner JD. 2009. Trichomonas vaginalis infection and Associated Risk Factors in a Socially-Marginalized Female Population in Coastal Peru. Infections Disease in Obstetrics and Gynecology, 6: 10-14.

Mazloumi A, Namazi A, Ghazanchaei A, Alizadeh S, Sehhati F, Rostamzadeh S,
Dolatkhah A. 2008. Prevalence and risk factors of trichomoniasis among women in Tabriz. Iranian Journal of Clinical Infectious Disease, 3(2): 6771.

Moodley P, Connolly C, Sturm WA. 2002. Interrelationship among Human Immunodeficiency Virus Type1 infection, Bacteria vaginosis, Trichomoniasis and the presence of yeast. The Journal of Infectious Diseases, 185: 69-73.

Nimorsi OP, Egwunyenga AO, Bajomo DO. 2001. Survey of Urinary Schistosomiasis and Trichomoniasis in rural community in Edo state, Nigeria. Journal of Communicable Diseases, 33(2): 96-101.

Nwankwo EOK, Kandakai YTO, Shuaibu SA. 2010. Aetiologic agents of Abnormal Vaginal Discharge among Females of Reproductive Age in Kano, Nigeria. Journal of Medicine and Biomedical Sciences, 3: 12-13.

Okonko IO, Akinpelu AO, Okeretugba PO. 2012. Prevalence of sexually transmitted infection among Attendees of AFRH centre in Ibadan, Nigeria. Middle-Earth Journal of Scientific Research, 11(1): 24-31.

Oladeinde BH, Omoregie R, Olley M, Anunibe JA.2011. Urinary tract infection in a rural community of Nigeria. North Amer. Journ. Med. Sci., 3(2): 75-77. DOI:10.4297/najms.2011.375 .

Olowe OA, Makanjuola OB, Olowe R, Adekanle DA. 2014. Prevalence of Vulvovaginal Candidiasis, Trichomoniasis and Bacterial Vaginosis among Pregnant Women receiving Antenatal care in Southwestern Nigeria. European Journal of Microbiology and Immunology, 4(4): 193-197. DOI: 10.1556/EUJMI-D-14-00027

Onuoha SC, Fatokun K. 2014. Prevalence and antimicrobial susceptibility pattern 
of Urinary tract infection (UTI) among pregnant women in Afikpo, Ebonyi, Nigeria. American Journal of Life Sciences, 2(2): 46-52. DOI: 10.11648/j.ajls.20 140202.12

Opara K, Udoidiung N, Atting I, Bassey F, Okol O, Nwabueze A.2008. Factor for Vaginal trichomoniasis among women in Uyo, Nigeria. The Internet Journal of Health, 9: 2-8.

Oyewole IO, Anyasor GN, Micheal-chikezie EC. 2010. Prevalence of Sexually Transmitted Infection pathogens in Human Immunodeficiency Virus infected and Non-infected women: Implication to Acquisition and Transmission of HIV in Nigeria. Asian Journal of Medicine Science, 2(3): 163166.

Ronald AR, Alfa MJ. 1996. Microbiology of the Genitourinary System. In: Medical Microbiology. $4^{\text {th }}$ edition. Galveston (TX): University of Texas Medical Branch at Galveston. Available from:
http://www.ncbi.nlm.nih.gov/books/NB K8136/

Valadkhani Z, Kazemi F, Assmar M, Amirkhani A, Esfandeariz B, Lotfi M, Ghobadirad S, Hassan N, Aghighi Z. 2010. Molecular Diagnosis of Trichomoniasis in Negative Samples Examined by Direct Smear and Culture. Iranian Journal of Parasitol, 5(4): 31-36.

Van der Pol B. 2007. Trichomonas vaginalis infection: The prevalent non vital sexually transmitted infection receives the least public health attention. Clinical Infectious Disease, 44: 23-25.

Wallin JE, Thompson SE, Zaidi A, Wong KH. 1981. Urethritis in women attending an STD clinic. British Journal of Venereal Diseases, 57: 5054.

World Health Organization. 2000. Global Prevalence and Incidence of Selected Curable Sexually Transmitted Infection. World Health Organization. 